\title{
EKSPLANASI SEJARAH \\ DAN IMPLIKASINYA DALAM PENGEMBANGAN MODEL PEMBELAJARAN SKI UNTUK MI
}

\author{
Nur Saidah \\ (Dosen PAI Institut Seni Indonesia Yogyakarta)
}

\begin{abstract}
Abstact
This article describes the explanation of history and its implications in the development of Islamic Culture History learning models in Islamic Primary School. As an independent science, history has a different methodology. Therefore, the explanation is different from the history of other scientific explanations, though conceptually adopted the theory of social and natural sciences to support the explanation. These rules include the historical explanation; regularity, generalization, statistical inference, periodical, bistorical narrative and the implications for the development of Islamic Culture History interpretation in Islamic Primary School learning model which requires teachers choose a model student-oriented learning (student centered). For an explanation of the history of the reconstruction of historical events that allow teachers to give crude learning materials so students should be involved to design his own knowledge until he is able to think. critically and learn many values from explanation history. One of the today's appropriate learning models is Contextual Teaching and Learning. This model is a holistic view of learners not only on psychological but also on social and neurotical. This model also requires the integral learning, bringing together the experience of learning in the classroom with daily experiences of students.
\end{abstract}

Keywords: explanation, contextual teaching and learning

\section{Pendahuluan}

Sejarah bukanlah kumpulan dari fakta, parade tokoh, kronologis peristiwa, atau deskripsi belaka yang apabila dibaca akan terasa kering karena kurang mempunyai makna. Fakta-fakta sejarah harus diinterpretasikan atau ditafsirkan agar sesuatu peristiwa dapat direkonstruksikan dengan baik, yakni dengan jalan menyeleksi, menyusun, mengurangi tekanan, dan menempatkan fakta dalam urutan kausal. Dengan demikian, tidak hanya pertanyaan dimana, siapa, bilamana, dan apa yang perlu dijawab, tetapi juga yang berkenaan dengan kata mengapa 
dan apa jadinya. Paparan sejarah secara subyektif memerlukan penjelasan yang rasional mengenai suatu fenomena historis.

Kuntowijoyo memaparkan bahwa ilmu sejarah merupakan ilmu yang terbuka. Hakikat dan kemandirian ilmu sejarah merupakan kekuatan yang mampu menjelaskan sejarah, sehingga perlu dibedakan antara penjelasan ilmu-ilmu alam dan ilmu sosial di satu pihak dan ilmu sejarah di pihak lain. Karena sejarah adalah ilmu yang mandiri. Mandiri, artinya mempunyai filsafat ilmu sendiri, permasalahan sendiri, dan penjelasan sendiri. ${ }^{1}$ Karena kemandirian ilmu sejarah tersebut maka muncul pertanyaan, apakah yang dimaksud dengan eksplanasi/penjelasan sejarah? Apa beda Penjelasan Sejarah dengan Penjelasan Ilmu Alam dan Penjelasan Ilmiah lainnya? Bagaimana implikasi penjelasan sejarah dalam pengembangan model pembelajaran SKI di MI? Tulisan singkat ini akan mencoba menjawab pertanyaan tersebut.

\section{Apakah Eksplanasi/Penjelasan Sejarah itu?}

Menurut Kuntowijoyo, Eksplanasi/Penjelasan sejarah (bistorical explanation) ialah usaha membuat satu unit sejarah intelligible (dimengerti secara cerdas). Kunto menegaskan perlunya intelligibility karena sejarah tidak hanya dijelaskan secara kausalitas. Kausalitas hanyalah salah satu dari penjelasan sejarah. Sedang tentang pertanyaan, mengapa sekedar "penjelasan" bukan "analisis" yang meyakinkan dan pasti? Kata "analisis" memang juga dipakai bergantian dengan "penjelasan", diantaranya oleh Marc Bloch, terutama ketika orang menganalisis hubungan kausal antar gejala sejarah. Akan tetapi, karena kata "penjelasan" lebih sesuai untuk sejarah pada umumnya, sedangkan kata "analisis" tidak sepenuhnya sesuai dengan hakikat ilmu sejarah, maka lebih tepat dipakai kata "pejelasan sejarah". Namun demikian, Kunto menyilakan bagi siapa saja yang ingin menyebut "penjelasan sejarah" dengan "analisis" sejarah. ${ }^{2}$

Penjelasan atau eksplanasi kaum historis didasarkan atas pendapat bahwa setiap peristiwa mempunyai keunikan dan individualitas, sehingga peristiwanya tidak dapat dianalisis dan direduksi. Setiap peristiwa hanya

${ }^{1}$ Kuntowijoyo, Penjelasan Sejarah (Historical Explanation), (Yogyakarta: Tiara Wacana, 2008), p. 2.

2 Ibid,p. 2 . 
perlu dilacak kembali ke peristiwa yang mendahuluinya. ${ }^{3}$ Sehingga dapat dikatakan bahwa eksplanasi sejarah adalah suatu proses yang menunjukkan peristiwa-peristiwa tertentu dihubungkan dengan peristiwa-peristiwa lain melalui penggunaan pernyataan-pernyataan yang bersifat umum yang tepat (general statements).

Sebagai ilmu, sejarah terikat pada prosedur penelitian ilmiah. Penelitian ilmiah merupakan sumber dan upaya pengembangan ilmu. Sejarah, karenanya, juga terikat pada penalaran (reasoning) yang mendasarkan diri pada fakta. Dalam sejarah dibedakan antara konsep data dan konsep fakta. Fakta adalah data-data yang telah teruji kebenarannya melalui uji (kritik) sumber. Fakta-fakta inilah yang menjadi andalan bagi kebenaran sejarah. Untuk memperoleh kebenaran sejarah, akan banyak bergantung pada kesediaan para sejarawan untuk meneliti dan mengkaji sumber sejarah secara cermat dan tuntas, sehingga diharapkan mampu mengungkap sejarah dengan objektif (atau mendekati objektif). Hasil final yang diharapkan ialah adanya kesesuaian (korespondensi) antara pemahaman (interpretasi dan historiografi) sejarawan dengan fakta.

Louis Gottschalk ${ }^{4}$ menyimpulkan bahwa prosedur penelitian dan penulisan sejarah bertumpu pada 4 (empat) kegiatan pokok, ialah :(1) Pengumpulan objek yang berasal dari suatu zaman dan pengumpulan bahan-bahan tertulis dan lisan yang relevan. (2) Menyingkirkan bahanbahan yang tidak otentik. (3) Menyimpulkan kesaksian yang dapat dipercaya dari bahan-bahan yang otentik. (4) Penyusunan kesaksian yang dapat dipercaya itu menjadi suatu kisah atau suatu penyajian yang berarti. Prosedur itulah yang disebut metode sejarah. Sesuai dengan langkahlangkah yang diambil dalam keseluruhan prosedur, metode sejarah biasanya dibagi atas 4 (empat) kelompok kegiatan, yakni :(1) Heuristik : kegiatan menghimpun sumber-sumber.sejarah. (2) Kritik (verifikasi) : meneliti apakah sumber-sumber itu sejati, baik bentuk maupun isinya. (3) Interpretasi : menetapkan makna dan saling hubungan dari fakta-fakta yang telah diverifikasi. (4) Historiografi : penyajian hasil sintesis yang

${ }^{3}$ Sartono Kartodirdjo, Pendekatan Ilmu Sosial dalam Metodologi Sejarah, Jakarta: Gramedia, cet. 2, 1993), p. 233.

${ }^{4}$ Louis Gottschalk, Understanding History: A Primer of Historical Method, Alfred A. Knopf: New York, 1987, p. 18. 
diperoleh dalam bentuk kisah sejarah. Posisi penjelasan sejarah/eksplanasi sejarah dalam metode sejarah dapat diilustrasikan sebagai berikut:

METODOLOGI SEJARAH

\begin{tabular}{|c|c|c|}
\hline \multicolumn{3}{|c|}{ METODE SEJARAH } \\
\hline $\mathbf{I}$ & $\begin{array}{c}\text { II } \\
\text { ANALISIS : }\end{array}$ & $\begin{array}{c}\text { IIII } \\
\text { HISTORIOGRAFI }\end{array}$ \\
\hline $\begin{array}{l}\mathbf{H} \\
\mathbf{E}\end{array}$ & \multirow{2}{*}{ Kritik Eksternal } & Penafsiran/Interpretasi \\
\hline $\mathbf{R}$ & & \multirow{2}{*}{ Penjelasan/Eksplanasi } \\
\hline $\begin{array}{l}\text { I } \\
\text { s }\end{array}$ & \multirow[b]{2}{*}{ Kritik Internal } & \\
\hline $\begin{array}{l}\mathbf{T} \\
\mathbf{I} \\
\mathrm{K}\end{array}$ & & Penyajian/Eksposisi \\
\hline
\end{tabular}

Dilihat dari langkah metodologi sejarah, secara kronologis penjelasan/eksplanasi sejarah merupakan kelanjutan dari interpretasi atas fakta. Hal ini sejalan dengan hakikat sejarah sebagai ilmu, sebagaimana diungkapkan Kuntowijoyo ${ }^{5}$ bahwa:

- SEJARAH: Menafsirkan, Memahami, Mengerti.

Sejarah bertumpu pada metode Verstenhen, yaitu pengalaman "dalam" yang menembus jiwa dan seluruh pengalaman kemanusiaan. Verstehen atau understanding adalah usaha untuk "meletakan diri" dalam diri yang "lain". Verstehen adalab mengerti "makna yang ada di dalam", mengerti subjective mind dari pelaku sejarah.

- SEJARAH : Memanjang dalam waktu, Terbatas dalam ruang.

Sejarah adalah ilmu diakronis, sedangkan ilmu sosial adalah ilmu sinkronis. Sejarah Ilmu diakronis sebab sejarah meneliti gejalagejala yang memanjang dalam waktu, tetapi dalam ruang yang terbatas. Sementara ilmu sosial lainnya seperti ilmu politik, sosiologi dan lain-lain, adalah ilmu sinkronis, yaitu ilmu yang meneliti gejala-gejala yang meluas dalam ruang, tetapi dalam waktu yang terbatas.

- SEJARAH : Menuturkan gejala tunggal

${ }^{5}$ Kuntowijoyo, Ibid, p. 2-10. 
Sejarah bersifat menuturkan gejala tunggal (ideographic, singularizing), sejarah menuturkan suatu obyek atau ide dan mengangkatnya sebagai gejala tunggal. Sementara ilmu sosial lain menarik hukum umum (nomothetic, generalizing), bermaksud menarik hukum karenanya mengangkat gejala-gejala umum.

Oleh karenanya, penjelasan sejarah adalah; 1) bermeneutic dan verstehen, menafsirkan dan mengerti, 2) penjelasan sejarah adalah penjelasan tentang waktu yang memanjang; 3) penjelasan sejarah adalah penjelasan tentang peristiwa tunggal. Penjelasan sejarah menurut Kunto adalah sintesa atas interpretasi terhadap fakta sejarah. Secara sederhana, dapat diilustrasikan sebagai berikut:

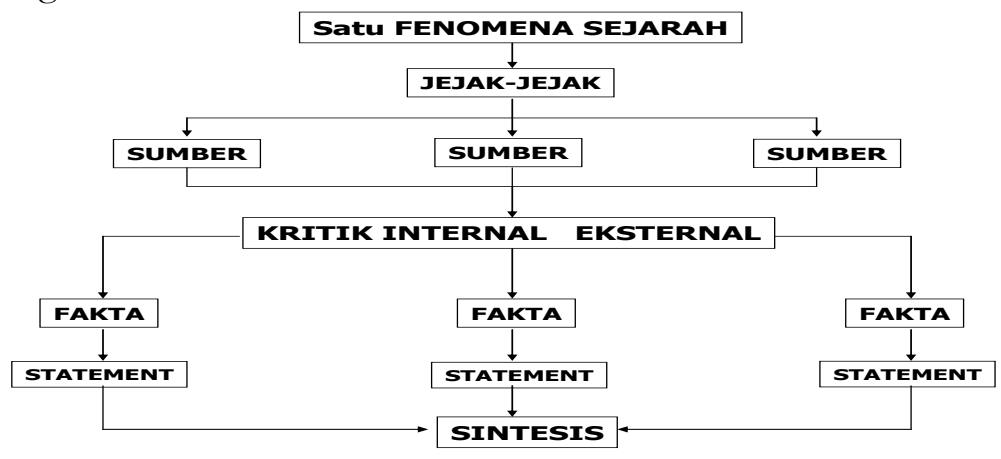

Tidak akan ada sintesis TANPA EKSPLANASI

\section{Apakah beda Penjelasan Sejarah dengan Penjelasan Ilmu Alam dan} Sosial? Perdebatan tentang apakah sejarah sebagai ilmu memiliki kesamaan dengan ilmu alam dan ilmu sosial lainnya telah berlangsung lama. Perdebatan tersebut melahirkan dua aliran besar dalam ilmu sejarah. Pertama, madzhab R.G.Collingwood (1935) yang menyatakan bahwa sejarah adalah buah pemikiran yang otonom berbeda dengan ilmu alam. Sementara madzhab kedua diusung oleh Carl Hempel (1942) bahwa alam diatur oleh hukum-hukum tertentu, demikian pula perbuatan manusia harus tunduk kepada prinsip-prinsip tertentu yang konstan dan universal. Aliran pertama dikenal dengan aliran humanistik (anti Hempelian), sedang aliran kedua dikenal dengan aliran positivistik (Hempelian). ${ }^{6}$

${ }^{6}$ Clayton Robert, The Logic of Historical Explanation, (USA: The Pennsylvania State University Press, 1996), p. vii. 
Jauh sebelum perdebatan tersebut, Wilhelm Dilthey (1833-1911), sebagaimana dikutip Kuntowijoyo ${ }^{7}$ menyatakan bahwa ilmu terbagi menjadi dua, yaitu ilmu tentang dunia "luar" atau Naturwissenschaften (ilmuilmu alam) dan ilmu tentang dunia "dalam" atau Geisteswissenschaften (ilmuilmu kemanusiaan, humanities, buman studies, cultural sciences). Dalam ilmuilmu kemanusiaan dimasukkannya sejarah, ilmu ekonomi, sosiologi, antropologi sosial, psikologi, perbandingan agama, ilmu hukum, ilmu politik, filologi, dan kritik sastra.

Sebagai ilmu humaniora, gejala sejarah (peristiwa, tokoh, perbuatan, pikiran, dan perkataan) tidak bisa dijelaskan dengan pendekatan yang digunakan untuk ilmu alam. Misalnya peristiwa gempa di Yogyakarta memang dapat dijelaskan dengan teori ilmu alam berdasarkan observasi geologis misalnya, namun hanya terbatas pada fenomena gempanya saja, tidak menyangkut penjelasan tentang apa yang dialami orang ketika peristiwa gempa, apa pikiran orang tentang gempa dan seterusnya. Oleh karenanya, pendekatan untuk ilmu kemanusiaan adalah dengan bermeneutics dan verstehen, menafsirkan dan memahami.

\begin{tabular}{l|l}
\multicolumn{2}{c}{ PERBEDAAN ILMU ALAM DENGAN SEJARAH } \\
\multicolumn{1}{c}{ ILMU ALAM } & \multicolumn{1}{c}{ ILMU SEJARAH } \\
Perulangan2/recurrence & $\begin{array}{l}\text { Peristiwa sejarah bersifat unik dan } \\
\text { partikularistik }\end{array}$ \\
$\begin{array}{l}\text { Percobaan/eksperimen di laboratorium } \\
\text { atau lapangan, yaitu mewujudkan } \\
\text { kembali bentuk semula dari gejala2 } \\
\text { semula }\end{array}$ & $\begin{array}{l}\text { Unsur paralelisme/kesejajaran } \\
\text { disamping kekhususan }\end{array}$ \\
$\begin{array}{l}\text { Mengidentifikasi keajegan/keteraturan } \\
\text { dari gejala tersebut }\end{array}$ & $\begin{array}{l}\text { Kecenderungan2 umum/general } \\
\text { tendencies }\end{array}$ \\
\hline $\begin{array}{l}\text { Keumuman/dalil/hukum bisa } \\
\text { dirumuskan }\end{array}$ & $\begin{array}{l}\text { Hukum-hukum sejarah bisa } \\
\text { dirumuskan }\end{array}$ \\
\hline
\end{tabular}

\section{Hukum Sejarah:}

"Tidak lain keteraturan yang dapat diserap pada sejumlah kejadian yang memberikan rupa/wujud persamaan pada perubahan-perubahan keadaan tertentu dalam seiarah"

${ }^{7}$ Kuntowijoyo, Ibid, p. 2-3. 
Beberapa perbedaan pokok penjelasan ilmu alam dan penjelasan sejarah dapat diuraikan sebagai berikut:

Penjelasan dalam Ilmu alamiah :

- Dimulai dengan observasi (pengamatan), berakhir dengan konsepkonsep umum (generalisasi).

- Gejala dilihat sebagai dalam kerangka suatu penegakan generalisasi Penjelasan dalam Sejarah :

- Berupaya untuk menyelami apa yang ada di dalam suatu peristiwa (dapat menghayati peristiwa sebenarnya dari dalam) :

$>$ Bagian luar adalah wujud fisik/gerak dari suatu peristiwa

$>$ Bagian dalam pikiran yang ada di balik wujud fisik

$>$ Re-thinking them in his own mind (konstruk pemikiran ulang tentang peristiwa sesuai pemahaman sejarawan berdasarkan fakta)

Dalam hal prediksi dan karakteriknya, ilmu alam dan sosial juga memiliki perbedaan sebagai berikut:

PREDIKSI ILMU ALAM \& SEJARAH

\begin{tabular}{|l|l|}
\hline \multicolumn{1}{|c|}{ ILMU ALAM } & \multicolumn{1}{c|}{ SEJARAH } \\
\hline Hukum / dalil yang pasti & Sulit melakukan prediksi karena keterbatasan perulangan \\
\hline Ketepatannya lebih besar & $\begin{array}{l}\text { Memproyeksikan pengalaman masa lampau ke situasi masa kini, } \\
\text { bahkan situasi yad meski tidak dengan landasan yang kokoh }\end{array}$ \\
\hline
\end{tabular}

KARAKTERISTIK

\begin{tabular}{|l|l|l|}
\hline \multicolumn{1}{|c|}{ SEJARAH } & \multicolumn{1}{c|}{ ILMU SOSIAL LAINNYA } & \multicolumn{1}{c|}{ ILMU ALAM } \\
\hline Temporal-spasial & A temporal-spasial & A temporal-spasial \\
\hline Diakronik & Sinkronik & Sinkronik \\
\hline Ideografik & Nomotetik & Nomotetik \\
\hline Partikularistik & Generalistik & Generalistik \\
\hline Einmalig & Berulangkali & Berulangkali \\
\hline Sumber terbatas & Eksperimen dan tes & Eksperimen / laboratorium \\
\hline Tidak dapat diukur & Dapat diukur & Dapat diukur \\
\hline Non-prediksi & Prediksi & Prediksi \\
\hline
\end{tabular}

Penjelasan sejarah dimungkinkan akan menjawab pertanyaan-pertanyaan yang sangat erat kaitannya dengan waktu yaitu continuity and change: 


\section{EKSPLANASI SEJARAH}

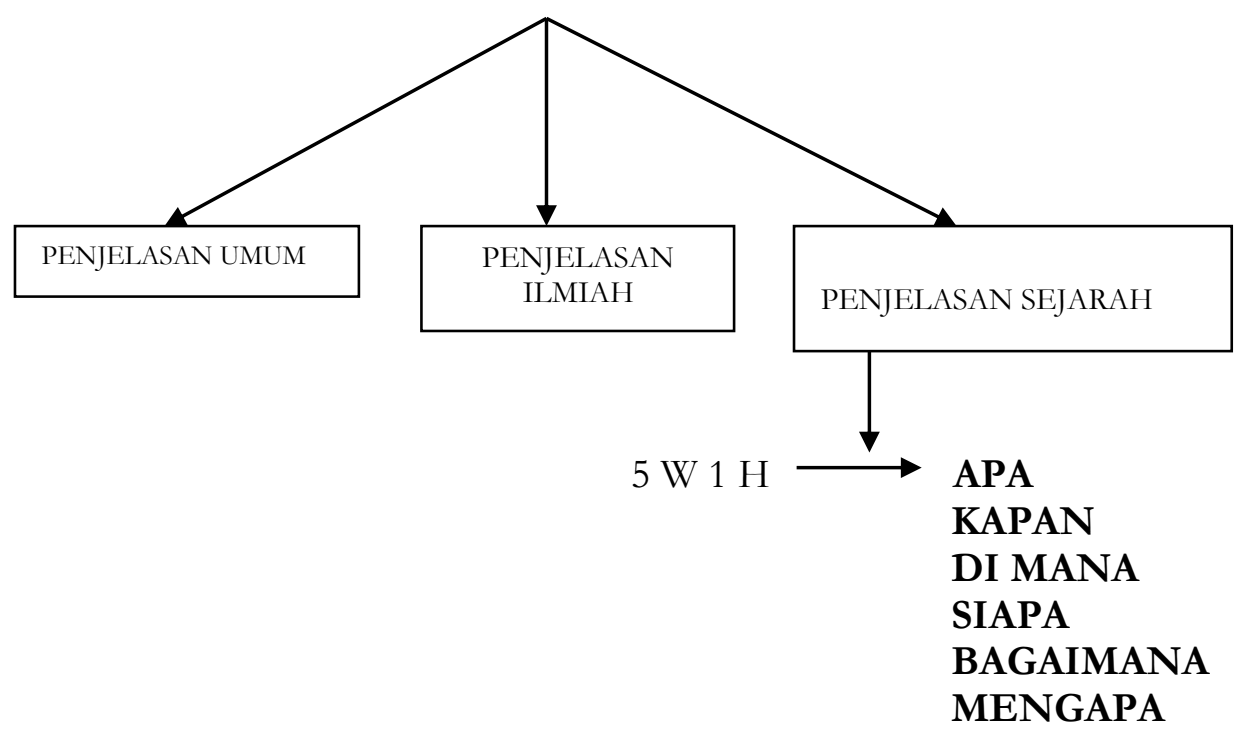

Terlepas dari perbedaan tersebut, problem besar dialami ilmu sejarah yaitu sejauh mana teori dalam ilmu sejarah dapat membantu penyusunan eksplanasi sejarah?, sedangkan dalam ilmu alam kerangka teoretis dengan hukum atau dalil-dalilnya mempermudah eksplanasi proses tersebut pada umumnya dan eksplanasi kausal khususnya. Dalam pada itu, sejarah dengan pendekatan ilmu sosial lebih mampu mengadakan analisis sehingga dapat melacak kausalitas gejala historis yang kompleks. ${ }^{8}$ Oleh karenanya, dalam menguraikan tentang penjelasan sejarah, Kuntowijoyo menggabungkan kedua pendekatan tersebut, yaitu pendekatan ilmu alam dan pendekatan ilmu sosial.

\section{Bagaimanakah Penjelasan Sejarah dilakukan?}

Menurut Djoko Suryo9, Kuntowijoyo telah berhasil meramu hakikat penjelasan sejarah (meskipun ada jenis penjelasan sejarah lain yang tidak disebutkan) yang selama tiga dekade pada abad XX telah menjadi bahan perdebatan dan ketidaksepakatan di antara kaum positivis dan kaum idealis (humanis dalam bahasa Clayton Robert). Kaum positivis, pada satu pihak, antara lain diwakili oleh Karl Popper dan Carl Hempel, dan kaum

${ }^{8}$ Sartono, Ibid, p. 233.

${ }^{9}$ Kuntowijoyo, Ibid, p. xiii. 
idealis, pada pihak lain, antara lain diwakili oleh Dilthey, Collingwood, Croce, dan Max Weber. ${ }^{10}$ Perdebatan ini antara lain berkisar pada persoalan sebagai berikut: haruskah semua penjelasan sejarah seragam dengan menggunakan model yang sama (deduksi) ataukah penjelasan dalam sejarah boleh memiliki logika sendiri?. Apakah kaum positivis benar ketika ia menyatakan bahwa secara metodologis tidak ada perbedaan mendasar antara sejarah dan ilmu alam?. Apakah sejarah (dipandang sebagai disiplin kognitif) sui generis atau tidak?. Haruskah sejarawan menggunakan hukum (atau generalisasi universal) seperti ahli ilmu alam atau dapatkah ia mencapainya dengan cara berbeda?.

Keberhasilan Kuntowijoyo dalam meramu teori tentang penjelasan sejarah adalah dengan mengungkapkan kaidah-kaidah penjelasan sejarah yang disederhanakan menjadi enam kaidah, kesemuanya diambilkan baik dari aliran positivis maupun humanis. Keenam kaidah tersebut adalah: ${ }^{11}$ Pertama : Regularity (keajekan, keteraturan, konsistensi (diambilkan dari konsep Gardiner; positivis). Regularity adalah penjelasan antar peristiwa yang mengandung prediksi sejarah menjadi pejelasan dalam peristiwa (inner coherence). Artinya secara ajek gejala-gejala muncul dimana saja terjadi suatu peristiwa. Contoh : pejelasan sejarah tentang sebab-musabab Revolusi Indonesia. Sekali diterangkan bahwa revolusi itu adalah revolusi pemuda, maka semua tempat peristiwa harus disebabkan oleh pemuda, baik dipusat maupun di daerah. Contoh lain; kalau ada kekosongan otoritas maka akan terjadi anarki. Itulah yang terjadi di Indonesia pada Mei 1998 dan juga di Baghdad pada April 2003.Bagi Kunto, semua penjelasan sejarah sebenarnya memerlukan regularity di dalamnya, terutama dalam menjelaskan aspek kausalitas.

\section{Kedua : Generalisasi (konsep dari McCullagh)}

Adalah persamaan karakteristik tertentu. "suatu bagian yang menjadi ciri sebuah kelompok, juga menjadi ciri dari kelompok yang lain pula". Konsep-konsep sejarah seperti "feodalisme", "puritanisme", dan "pergerakan nasional" semuanya mengandung generalisasi konseptual.

${ }^{10}$ Menurut Clayton Robert, kelompok positivis didukung oleh Carl Hempel, Ernest Nagel, Morton White, Patrick Gardiner dan Robert Stover. Sementara kelompok humanis didukung oleh William Dray, Alan Donagan, Michael Scriver, R.F. Atkinson dan A.R. Louch. (Clayton Robert, Ibid, p. vii.)

${ }^{11}$ Kuntowijoyo, Ibid, p. 10-18. 
Generalisasi sejarah ialah membandingkan unit-unit sejarah. Letak penjelasan sejarahnya ialah pada generalisasi itu, tidak pada deskripsi atas masing-masing unit sejarah. Konsep Generalisasi diambilkan dari ilmu alam dan ilmu sosial, namun yang membedakannya adalah generalisasi dalam sejarah sangat berkait dengan waktu sehingga dalam pengeneralisasiannya seorang sejarawan akan menyusun periodisasi (generalisasi periodik).

\section{Ketiga : Inferensi Statistik, Metode Statistik. (konsep dari McCullagh)}

Inferensi statistik dan metode statistik menjadi andalan dalam generalisasi. Kuantifikasi sebagaimana dalam tradisi sejarah sebenarnya hanya menjelaskan narasi. Jadi, bukan merupakan penjelasan numerikal dan statitikal. Pada dasaranya sejarah itu persoalan kualifikatif.

Keempat: Pembagian waktu dalam sejarah (konsep dari Fernand Braudel)

Sejarawan melakukan klasifikasi atas waktu, sejarawan membuat periodisasi. Realitas sejarah sendiri terus-menerus mengalir tanpa sekatsekat, dan pembabakan waktu adalah hasil konseptualisasi sejarawan, suatu rasionalisasi. Rasionalisasi bukan generalisasi. Rasionalisasi lahir dari pemikiran teoritis, sedangkan generalisasi adalah hasil dari gejala empiris.

\section{Kelima : Narrative History}

Sejarah adalah cerita masa lalu. Tugas sejarawan adalah menyusun bersama secara teratur. Susunan yang teratur itu sendiri tidak terdapat dalam gejala sejarah, tetapi justru tugas sejarawanlah untuk membuatnya teratur. Cara sejarawan menyusun adalah dengan merekonstruksi masa lalu, menghubungkan fakta yang satu dengan yang lainnya, sehingga terbentuklah suatu cerita.

Keenam : Multi-Interpretable (konsep Lorenz)

Bahwa ilmu sejarah yang dipahami sebagai menafsirkan, memahami dan mengerti, cukup menjelaskan adanya subyektivisme dan relativisme dalam penjelasan sejarah. Sehingga sejarah bakal Multi-Interpretable. Sebagai akibatnya bisa jadi dalam mencari sebab musabab sebuah peristiwa terdapat perbedaan-perbedaan tafsir.

Berkait dengan model penjelasan sejarah yang menawarkan jalan tengah antara madzhab positivis dan humanis, Clayton Robert mengungkapkan perlu adanya penjelasan sejarah yang total (total explanation). Yaitu penjelasan dimana sejarawan mula-mula 
mendeskripsikan kejadian/peristiwa yang kompleks yang harus dijelaskan. Kemudian jejak-jejak sejarah yang memiliki keunikan dijadikan fokus, untuk kemudian dicari siapa yang menjadi aktor utama peristiwa tersebut, menguraikan tujuan-tujuan mereka yang dihubungkan dengan hasrat dan kepercayaan aktor tersebut. Akhirnya dengan penjelasan total tersebut diperoleh pemahaman yang didasarkan pada sebab-sebab utama sebuah peristiwa. $^{12}$

Dalam proses penjelasan total tersebut, Clayton Robert menekankan pentingnya prinsip koligasi (colligation) dan korelasi (correlation). Prinsip koligasi adalah : prosedur menerapkan suatu peristiwa dengan jalan menelusuri hubungan intrinsik dengan peristiwa lain ; mencari kecenderungan umum. Sementara prinsip korelasi adalah prosedur menelusuri keterkaitan suatu peristiwa dengan peristiwa yang lain. ${ }^{13}$ Dengan pola penyederhanaan terhadap nalar penjelasan sejarah seperti yang dilakukan Clayton Robert, nampaknya mirip dengan apa yang dikemukakan Kuntowijoyo dengan kaidah Narrative History/sejarah naratif, bahwa menulis sejarah naratif antara lain dilakukan dengan cara koligasi (mencari hubungan dalam antar peristiwa sejarah), lalu membuat plot (mengorganisasikan fakta-fakta menjadi satu keutuhan) dan struktur sejarah (menyusun rekonstruksi secara akurat). ${ }^{14}$ Dengan demikian sejarah naratif bukan sekedar menjejerkan fakta melainkan menyusun rekonstruksi sebuah peristiwa menjadi rangkaian penjelasan historis yang utuh sekaligus kritis.

\section{Implikasi Penjelasan Sejarah dalam pengembangan model pembelajaran di MI}

Pembelajaran sejarah di sekolah umumnya dianggap tidak menarik, akibatnya banyak anak sekolah yang kurang tertarik untuk mendalami Mata Pelajaran Sejarah. Selain itu ada anggapan bahwa mata pelajaran Sejarah tidak terlalu penting sehingga siswa dalam proses belajar mengajar tidak serius dalam mengikutinya. ${ }^{15}$ Beberapa indikator yang menunjukkan bahwa mata pelajaran sejarah tidak menarik atau penting adalah nilai-nilai

12 Clayton Robert, Ibid, p. ix.

${ }^{13} \mathrm{Ibid}$, p. viii.

${ }^{14}$ Kuntowijoyo, Ibid, p.147-148.

${ }^{15}$ Kasmadi, Hartono.. PengembanganPembelajaran Dengan Pendekatan ModelModel Pengajaran Sejarah. Semarang:PT. Prima Nugraha Pratama. 2001, p. 6. 
pelajaran sejarah tidak cukup tinggi, serta program Ilmu Sosial (IS) di tingkat SMA dianggap sebagai program nomor dua setelah Ilmu Alam (IA). Dalam skala yang lebih luas, Sanusi melihat bahwa pengajaran IPS termasuk sejarah di sekolah cenderung (1) menitikberatkan pada penguasaan hafalan; (2) proses pembelajaran yang berpusat pada guru; (3) terjadinya banyak miskonsepsi; (4) situasi kesal yang membosankan siswa; (5) ketidaklebihunggulan guru dari sumber lain; (6) ketidakmutakhiran sumber belajar yang ada; (7) sistem ujian yang sentralistik; (8) pencapaian tujuan kognitif yang „mengkulit bawang“; (9) rendahnya percaya diri siswa sebagai akibat dari amat lunaknya isi pelajaran, kontradiksi materi dengan kenyataan, dominannya latihan berpikir taraf rendah, guru yang tidak tangguh, persepsi negatif dan prasangka buruk dari masyarakat terhadap kedudukan dan peran IPS dalam pembangunan masyarakat. ${ }^{16}$

Hal tersebut di atas disebabkan adanya beberapa faktor. Faktor pertama adalah penempatan jam pelajaran Sejarah biasanya sebagai pelengkap, di siang hari ketika kondisi belajar siswa sudah menurun. Faktor kedua adalah performance guru sejarah. Di banyak MI mata pelajaran Sejarah diampu oleh guru dengan latar belakang bukan dari jurusan Sejarah. Faktor ketiga adalah sajian materi dalam buku-buku Sejarah kurang memadai. Buku-buku Sejarah umumnya tebal dengan bahasa baku yang sulit dicerna oleh siswa. Faktor keempat adalah faktor model pembelajaran dan dukungan media pembelajaran yang kurang memadai. Banyak guru Sejarah menyampaikan pembelajarannya hanya dengan ceramah atau tanya jawab, atau bahkan mencatat buku di papan tulis. ${ }^{17}$

Berkait dengan pembelajaran SKI di MI, kiranya analog dengan tulisan Djoko Suryo ${ }^{18}$ mengenai pembelajaran sejarah patut dipertimbangkan. Bahwa pembelajaran SKI dituntut paling tidak dapat mengaktualisasikan dua hal yakni: (1) pendidikan dan pembelajaran intelektual, melihat perkembangan Islam secara kritis-objektif, pendidikan dan pembelajaran moral bangsa, menyangkut kearifan dan

16 Sanusi, Fatah.. IPS Sejarah. Jakarta:Direktorat PLP. 1998, p.222-227.

17 Velarasi, Aldilla Dhika. 2004. "Aku danPelajaran Sejarah”, Makalah Diskusi Pendidikan Sejarah di Era Pembangunan. 3-4 September 2004.Yogyakarta,p.7.

${ }^{18}$ Djoko Suryo(1996). "Pengembangan Kajian Sejarah dalam Kurikulum SLTA" Makalah, disampaikan pada acara seminar dalam rangka Dies Natalis IKIP Semarang, 13 Maret 1991,p. 11. 
ketaqwaan, terkait dengan nilai-nilai ke-Islaman. Hal yang pertama menuntut pembelajaran sejarah tidak hanya menyajikan pengetahuan faktual, namun dituntut untuk memberikan latihan berfikir kritis, mampu menarik kesimpulan, memahami makna dari suatu peristiwa sejarah perkembangan Islam menurut kaidah dan norma keilmuan. Pertanyaanpertanyaan mengenai mengapa dan bagaimana, penting untuk dikembangkan dalam proses pembelajaran SKI. Sementara itu hal yang kedua menunjuk pada pembelajaran sejarah yang berorientasi pada pendidikan kemanusiaan yang memperhatikan moralitas, ketaqwaan, dan nilai-nilai ke-Islaman lainnya.

Dengan mengembangkan dua hal : pendidikan intelektual dan pendidikan moral atau pendidikan kemanusiaan, maka arah pembelajaran SKI diharapkan dapat mencapai tujuan yang menopang tercapainya tujuan pendidikan nasional. Pembelajaran SKI akan dapat melandasi pendidikan kecerdasan intelektual, sekaligus ikut mendasari pendidikan yang berorientasi pada kecerdasan emosional bahkan kecerdasan spiritual dalam rangka meningkatkan martabat manusia Indonesia yang religius.

Mencermati rumusan tersebut, nampak jelas bahwa di samping aspek kognitif, dimensi afektif menempati porsi yang cukup penting dalam tujuan pembelajaran SKI. Namun dalam kenyataannya timbul kritik bahwa pendidikan sejarah cenderung intelektualistik-kognitif dan pragmatis. Padahal, sebagai ilmu yang terbuka yang memiliki kekhasannya dalam aspek penjelasan sejarah amat memungkinkan bagi pendidik untuk mengembangkan model pembelajaran sejarah yang sarat nilai, menemukan makna dari penjelasan sejarah yang unik, sekaligus membiasakan siswa berfikir kritis.

Persoalan di atas, barangkali muncul karena ada upaya penyederhanaan penjelasan sejarah yang seharusnya sarat dengan muatan nilai menjadi mata pelajaran yang dititikberatkan pada penghafalan fakta sejarah, baik peristiwa, pelaku maupun tempatnya yang kering dari nilainilai yang seharusnya diteladani peserta didik. Oleh karenanya, menyajikan penjelasan sejarah yang memadai dan dimengerti peserta didik adalah keniscayaan bagi seorang pendidik.

Dalam memilih penjelasan sejarah dan mengembangankan model pembelajaran SKI yang tepat, seorang pendidik perlu mempertimbangkan 
karakteristik peserta didik. Secara umum karakteristik siswa Madrasah Ibtidaiyah adalah memiliki minat terhadap kehidupan praktis yang konkrit, mulai berpikir komparatif dan realistik, punya rasa ingin tahu yang besar dan karena itu mempunyai dorongan belajar yang kuat, punya kecenderungan pada satu jenis pelajaran, membutuhkan orang lebih dewasa untuk dijadikan idola, mampu mengukur kemampuan sendiri, dan gemar hidup berkelompok dengan teman sebayanya. ${ }^{19}$

Berpijak pada pemahaman atas karakteristik siswanya, seorang guru di lingkungan belajar sejarah hendaknya mengarahkan siswanya tidak hanya mempelajari informasi baik berupa data dan cerita masa lalu melainkan juga mempelajari bagaimana hidup ala sejarah. Artinya, siswa tidak dijadikan oleh guru untuk menjadi bank pengetahuan sejarah, mereka juga dibimbing untuk melakukan studi sejarah sesuai dengan kemampuannya. Guru dituntut untuk memilih penjelasan sejarah yang memadai dari berbagai bahan ajar naratif yang variatif, juga perlu menghadirkan gambar, dokumen, benda-benda bersejarah dan mengunjungi tempat-tempat bersejarah. ${ }^{20}$ Oleh karena itu, untuk meningkatkan peran serta siswa dalam proses belajar perlu diupayakan melalui pemilihan metode tertentu yang tepat. Hal ini dilakukan agar kualitas pembelajaran sejarah semakin meningkat sehingga hasil belajar pun semakin optimal.

Berdasarkan kekhasan penjelasan sejarah, implikasi dalam pengembangan model pembelajaran SKI di MI menuntut pendidik/guru memilih model pembelajaran yang berorientasi pada siswa (student centered). Sebab penjelasan sejarah merupakan rekonstruksi peristiwa sejarah yang memungkinkan guru memberikan materi pembelajaran mentah sehingga siswa memiliki kesempatan untuk menyusun materi itu menjadi pengetahuan yang sesuai dengan kemampuannya. Akhirnya pembelajaran menjadi lebih bermakna karena peserta didik dilibatkan untuk meracik, meramu, dan merakit pengetahuannya sendiri. ${ }^{21}$

Salah satu model pembelajaran yang tepat digunakan saat ini adalah Contextual Teaching and Learning karena model ini bersifat holistik.

\footnotetext{
${ }^{19}$ M. Hanafi, Pembelajaran SKI, (Jakarta: DirJen PenDis DEPAG RI, 2009), p.44.

${ }^{20} \mathrm{Ibid}, \mathrm{p.} 24-25$.

${ }^{21}$ M. Hanafi, ibid, p. 155.
} 
Artinya, model ini melihat peserta didik tidak hanya dari sisi psikologi tetapi juga sosial dan neurofisik. Model ini juga mensyaratkan adanya pembelajaran yang integral, menyatukan pengalaman belajar di kelas dengan pengalaman sehari-hari peserta didik. Varian metode belajar dalam lingkup CTL yang tepat untuk pembelajaran sejarah amat beragam, misalnya untuk membelajarkan konsep bisa memakai metode scrable (kata acak), make a match (mencari pasangan),word square (kotak kata) dan sebagainya. Guna meningkatkan pemahaman siswa terhadap penjelasan sejarah yang dipelajarinya, dapat digunakan metode Time Line (Garis Waktu) yang memuat waktu tertentu dan memberikan kesempatan kepada siswa untuk merekonstruksi penjelasan sejarah sesuai waktu yang tertulis. Bisa juga digunakan metode Story Board Telling (Papan Bercerita), yaitu papan cerita yang berisi kotak/kantong kartu-kartu bergambar yang di baliknya berisi kata kunci sebuah peristiwa sejarah. Siswa dipersilakan memilih satu kotak kartu lalu diminta menceritakan peristiwa sejarah yang terdapat di kartu-kartu tersebut secara kronologis. Di samping itu, menyesuaikan dengan gaya belajar anak MI yang masih didominasi gaya kinestetik (siswa bisa belajar dengan baik kalau seluruh anggota tubuhnya dilibatkan), maka siswa harus diberi kesempatan gerak di dalam kelas supaya bisa belajar dengan efektif. Beberapa metode yang dapat mendorong keaktifan, keefektifan, dan keafektifan siswa di kelas antara lain physical self assessment (guru menempelkan tanda S (setuju), TS (tidak setuju) atau B (benar) dan S (salah) di dinding, lalu siswa diminta memilih dan menempatkan diri di bawah tanda tersebut setelah mendengarkan pernyataan yang berisi materi dari guru), information search (cari info), maupun role playing (bermain peran). ${ }^{22}$

Metode pembelajaran lain yang dapat diterapkan adalah cooperative learning atau belajar secara berkelompok. ${ }^{23}$ Metode ini membawa siswa sebagai anggota kelompok untuk memecahkan masalah atau menyelesaikan tugas secara bersama-sama. Dengan belajar kelompok siswa dapat termotivasi untuk belajar bersama atau untuk dapat melatih anakanak berpikir dan memahami materi pelajaran agar tidak tertinggal dari

22 Lihat lebih lanjut, M. Hanafi, Pembelajaran SKI, (Jakarta: DirJen PenDis DEPAG RI, 2009), p.195-220.

${ }^{23}$ Solihatin, Etin dan Raharjo. Metode Cooperative Learning Dalam Pengajaran Sejarah. Jakarta: PT. Gramedia. 2007, p.5. 
teman-temannya. ${ }^{24}$ Metode apapun dapat digunakan sepanjang mendorong siswa untuk lebih aktif memahami penjelasan sejarah yang dipelajarinya dan memungkinkannya merajut sendiri pengetahuannya.

Namun satu hal yang perlu mendapat perhatian, seiring dengan kondisi pembelajaran sejarah pada umumnya, adanya kritik bahwa pendidikan nasional yang terlalu intelektualistik, serta kondisi generasi muda yang mulai melemah rasa nasionalismenya, maka model pembelajaran SKI berbasis nilai, apalagi dikaitkan dengan aspek spiritualisme, merupakan hal yang sangat strategis dalam rangka membangun karakter bangsa. Dalam menghidupkan nilai guna mencapai kesadaran sejarah dari penjelasan sejarah yang diperoleh, guru dituntut untuk mampu menggali nilai-nilai yang sebenarnya sudah dimiliki siswa namun terkadang belum terimplementasikan dalam kehidupan sehari-hari. Di antara cara menghidupkan nilai sejarah adalah dengan membuat/meminta siswa menyanyi, membaca puisi, berita, permainan, ataupun memainkan drama yang dihadirkan dari penjelasan sejarah. Pada intinya, dengan memahami bahwa sejarah merupakan ilmu terbuka dengan penjelasannya yang kaya, memungkinkan seorang guru untuk mengkreasikan model pembelajarannya dengan lebih menarik dan menantang siswa namun tetap berpijak pada data-data sejarah yang akurat.

${ }^{24}$ Anita Lie. Cooperative Learning. Jakarta:PT. Gramedia. 2002,p. 18. 


\section{Penutup}

Berdasarkan uraian singkat di atas, diperoleh kesimpulan bahwa sebagai ilmu yang mandiri sejarah memiliki kekhasan dalam metodologinya. Diantaranya dalam hal penjelasan sejarahnya yang berbeda dengan penjelasan ilmiah lainnya, meskipun secara konseptual sejarah mengadopsi teori sosial maupun ilmu alam untuk mendukung penjelasannya agar menjadi ilmiah.

Sesuai dengan hakikatnya, bahwa sejarah adalah memahami, menafsirkan dan mengerti maka penjelasan sejarah merupakan langkah kunci agar konstruksi sejarah tidak kronik, melainkan diakronik, memanjang dalam waktu meskipun yang dituturkan adalah gejala tunggal.

Kaidah-kaidah penjelasan sejarah meliputi; regularity, generalisasi, inferensi statistik, periodisasi, sejarah naratif dan multi interpretasi. Teori penjelasan sejarah yang representatif dengan pemaparan sejarah dan sesuai pula dengan kekhasan sejarah sebagai disiplin ilmu mandiri adalah kaidah narrative history / sejarah naratif yang dikemukakan Kunto. Atau dengan bahasa lain, Total Explanation yang dikemukakan Clayton Robert yang menekankan pentingnya prinsip koligasi (prosedur menerapkan suatu peristiwa dengan jalan menelusuri hubungan intrinsik dengan peristiwa lain ; mencari kecenderungan umum) dan prinsip korelasi (prosedur menelusuri keterkaitan suatu peristiwa dengan peristiwa yang lain). Kemudian barulah disusun plot dan struktur sejarah yang akan menghadirkan konstruk sejarah yang utuh sebagai peristiwa yang tidak hanya dijelaskan dengan kausalitas saja.

Dengan demikian, dalam upaya mengembangkan model pembelajaran SKI, penjelasan sejarah berimplikasi pada pengembangan model pembelajaran siswa aktif. Sifat penjelasan sejarah yang multi interpretasi mengharuskan guru mengajak siswanya berfikir kritis, meramu dan merekonstruksi pengetahuannya sendiri dengan tetap mendasarkan interpretasinya pada fakta sejarah. Di antara model yang dapat diterapkan adalah CTL dengan berbagai metodenya yang variatif dan menyenangkan. 


\section{DAFTAR PUSTAKA}

Burke, Peter., , Sejarah dan Theori Sosial. Jakarta: yayasan Obor. 2001.

Gottschalk, Louis. Understanding Hitory: A Primer of Historical method. Alfred A.

Knopf: New York, 1987

Hanafi, M. Pembelajaran SKI. Jakarta: DirJen PenDis DEPAG RI, 2009.

Hempel.G. Carl., , " The Function of General Laws in History”. Dalam Patrick

Gardiner, Theories of History. New York: The Free Press and London:

Collier Macmillan Publishers. 1959.

Kartodirdjo, Sartono. Pendekatan Ilmu Sosial dalam Metodologi Sejarah, (Jakarta: Gramedia, cet. 2, 1993

Pemikiran dan Perkembangan Historiografi Indonesia, Suatu Alternatif, Jakarta: Gramedia, 1982.

Kasmadi, Hartono.. PengembanganPembelajaran Dengan Pendekatan Model-

Model Pengajaran Sejarah. Semarang:PT. Prima Nugraha Pratama. 2001,

Kuhn S, Thomass., 1993., Peran Paradigma Dalam Revolusi Sains. Terjemahan.

Bandung: Remaja RosdakaryaKuntowijoyo, Penjelasan Sejarah (Historical Explanation), Yogyakarta: Tiara Wacana, 2008.

Kuntowijoyo, Penjelasan Sejarah (Historical Explanation), Yogyakarta: Tiara Wacana.2008.

Metodologi Sejarah,. Yogyakarta: Tiara Wacana, 2003.

Robert, Clayton. The Logic of Historical Explanation, USA: The Pennsylvania State University Press, 1996.

Sanusi, Fatah.. IPS Sejarah. Jakarta:Direktorat PLP. 1998

Solihatin, Etin dan Raharjo. Metode Cooperative Learning Dalam Pengajaran Sejarah. Jakarta: PT. Gramedia. 2007

Suryo, Djoko. "Pengembangan Kajian Sejarah dalam Kurikulum SLTA" Makalah, (disampaikan pada acara seminar dalam rangka Dies Natalis IKIP Semarang, 13 Maret 1991).1996). 